responsible party model and demonstrate how American parties deviate from it. This is helpful but is further enhanced when one demonstrates that the traits of responsible parties can and do have real world expressions, and are not simply the product of an academic imagination.

Indeed, the fundamental goal of any educational program should be to equip students to succeed after they leave the university. One baseline test of this would be to ask ourselves if the things we expect students to learn will be useful to them in the next century. I imagine knowledge of marble cake federalism will not, whereas understanding why many countries have elections before the parliament has reached its term will at least enable them to understand a newspaper article. But these improvements will not come about until American political scientists take the scientific imperative seriously and place the study of American politics in a global context.

\section{Notes}

*The author would like to thank Mark Brandon, Gary Copeland, and Luz-Eugenia Köeck-Fuenzalida for their comments on an earlier draft of this article.

\section{References}

Almond, Gabriel. 1988. "Separate Tables: Schools and Sects in Political Science." PS: Political Science \& Politics, 21(4): 828-42.

Dalton, Russell J., Scott Flanagan, and Paul Beck, eds. 1984. Electoral Change: Realignment and Dealignment in Advanced Industrial Societies. Princeton: Princeton University Press.

Diamant, Alfred. 1990. "Comparative Politics: The Myth of the Eternal Return." PS: Political Science \& Politics, 23(4): 598-600.

Domínguez, Jorge I. 1987. "Political Change: Central America, South America, and the Caribbean." In Myron Weiner and Samuel P. Huntington, eds., Understanding Political Development. Boston: Little, Brown and Co.

Hartz, Louis. 1955. The Liberal Tradition in America. New York: Harcourt Brace and World.

Heidenheimer, Arnold, Hugh Heclo, and Carolyn Teich Adams. 1990. Comparative Public Policy: The Politics of Social Choice in America, Europe, and Japan, 3rd ed. New York: St. Martin's Press.

Lijphart, Arend. 1975. The Politics of Accommodation: Pluralism and Democracy in the Netherlands, 2nd ed. Berkeley: University of California Press.

Loewenberg, Gerhard, and Samuel C. Patterson. 1979. Comparing Legislatures. Boston: Little, Brown and Co.

Lowi, Theodore J. 1991. "The Politics of the Republican Era - and the Future of the Republic." Julian J. Rothbaum Distinuished Lecture in Representative Government, The Carl Albert Center, Nor-

\title{
Teaching Political Science in a Foreign Language
}

\author{
Michael A. Morris, Clemson University
}

\section{Trying a New Approach}

The most direct, comprehensive way to integrate foreign languages into the U.S. political science curriculum is to teach undergraduate political science courses in a foreign language. This author has taught three such political science courses in Spanish in successive semesters with an average enrollment of about 15 students each time. This sequence began with the spring semester of 1991 , and a fourth foreign-language political science course was to be taught in the fall semester of 1992. The courses in question are mainline political science courses often taken by majors in the department (international politics and third world politics).

Replicating this approach should be possible in the undergraduate curricula of other U.S. universities. Few man, Oklahoma, 24 October.

Lowi, Theodore J. 1979. The End of Liberalism: The Second Republic of the United States, 2nd ed. New York: W.W. Norton.

Nice, David C. 1987. Federalism: The Politics of Intergovernmental Relations. New York: St. Martin's Press.

Patrick, Glenda M. 1984. "Political Culture." In Giovanni Sartori, ed., Social Science Concepts: A Systematic Analysis. Beverly Hills: Sage.

Riggs, Fred W. 1991. "Public Administration: A Comparativist Framework." Public Administration Review, Nov./Dec. 51(6): 473-77.

Rose, Richard. 1989. "How Exceptional Is the American Political Economy?" Political Studies Quarterly 104(1): 91-211.

Sartori, Giovanni. 1991. "Comparing and Miscomparing." Journal of Theoretical Politics, 3(3): 243-57.

Searing, Donald D. 1991. "Roles, Rules, and Rationality in the New Institutionalism." American Political Science Review, 85(4): 1239-60.

Wildavsky, Aaron. 1987. "Doing More and Using Less: Utilisation of Research as a Result of Regime." In Comparative Policy Research: Learning from Experience, eds. Meinolf Dierkes, Hans N. Weiler and Arianne Bertoin Antal. New York: St. Martin's Press.

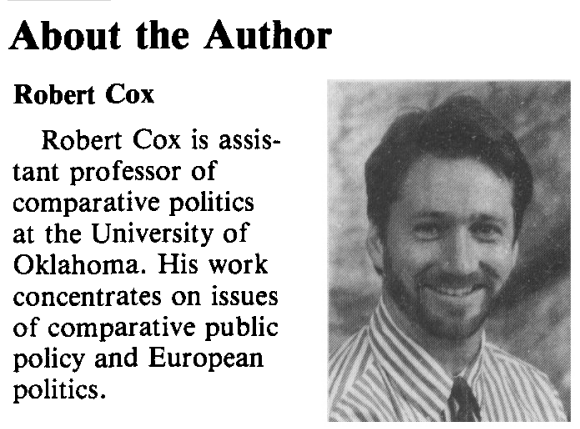

particular circumstances favor such an approach at Clemson University other than a supportive administration, while some aspects of the situation would seem to militate against it. For example, only three of the students in the foreign-language sections have been native Spanish speakers, which is not surprising as there is no sizable Hispanic community in South Carolina. Since Clemson University is a technically 
oriented, land grant university, there is only a modest body of liberal arts majors from which to draw for foreign-language courses in the social sciences. Clemson's department of political science has about 300 majors, and a new degree program in language and international trade in the department of languages has about 250 majors. Both departments have been exclusively oriented toward undergraduate education, although the political science department is adding a master of public administration program.

Language competency was another factor necessarily limiting enrollment in the courses. A prerequisite for enrolling in the political science courses in Spanish was completion of at least Spanish 202 (that is, completion of at least the second semester of an intermediate or second-year course in college-level Spanish). All liberal arts majors must take two full years of a foreign language, although language requirements of the other colleges in the university are more lenient.

There is a logical elegance to teaching political science courses to Americans in a foreign language. What better way to internationalize the U.S. political curriculum than to teach courses in a foreign language and to rely on foreign language materials? But the approach was not without problems, not least of which is that it had not been done before.

\section{Alternative Approaches}

Teaching political science to American undergraduates in a foreign language might be deemed a maximalist approach to internationalization of the curriculum in contrast to a number of other possibilities that may be categorized jointly as a minimalist approach. A few undergraduate political science courses at other universities involve some kind of foreign language component but, being of fairly limited scope, they may be deemed minimalist in nature. All such approaches would appear to be steps in the right direction, but the logic of a maximalist approach is to rely as much as possible on foreign-language readings and to conduct as much of the class in the foreign language as possible.

\section{Obstacles}

Teaching political science to American undergraduates in a foreign language is a new approach that questions a variety of established practices. Queries included the following in my case. Wouldn't a section of a political science class taught in a foreign language constitute a new course, and hence have to receive curricular approval at all appropriate levels? Wouldn't the concept be so new as to scare off the typical undergraduate? Wouldn't foreign language teaching in the political science department encroach on the language department and

\section{What better way to internationalize the U.S. political science curriculum than to teach courses in a foreign language and to rely on foreign language \\ materials?}

detract from enrollment of advanced language courses?

Where there is a will, there is a way. The active support of my former department head, Charles Dunn, and college dean, Robert Waller, among others, greatly facilitated acceptance of the new approach. Explanations to the language faculty convinced all concerned that foreign language teaching in the political science department would have a synergistic effect for all concerned. In fact, the Spanish section voted unanimously in favor of the approach. Clemson's new undergraduate program in languages and international trade ( $\mathrm{L}$ and IT) with about 250 majors constituted a sizable body of students with foreign-language expertise who needed to satisfy a social science requirement. $L$ and IT Director Jose Suarez has strongly recommended that students in the Spanish option take my Spanishlanguage courses in political science. This support has been strongly reinforced by the enthusiastic endorse- ment of the language department head, Judith Melton.

One indicator of the synergistic effect of political science courses in a foreign language is study abroad. While Clemson University does not have a junior year abroad program, it does have summer study programs abroad in French, German, and Spanish. Some students have come into my Spanish-language classes directly from these study-abroad experiences, and my classes have in turn reinforced the determination of still other students to participate in a summer abroad program.

Since political science courses have not previously been taught to mainstream U.S. undergraduates in a foreign language, there is a paucity of appropriate materials. Some syllabi of upper-division political science courses do include some foreign-language entries, but these are not generally required and moreover are usually journal articles written in technical, complex prose. In light of the lack of appropriate foreign-language material, it was judged necessary-at least in the initial stage of the experiment-to leave most of the basic readings for the courses in English. Instead, supplementary, required readings were in Spanish. What was sought was a body of required readings in the foreign language in a format accessible to undergraduates with only a few years of prior language training. It was decided to require a daily newspaper or weekly newsmagazine in a foreign language, and to link these foreign-language sources to class assignments.

The choice of a supplementary, required Spanish-language source was not easy. While major U.S. national newspapers and news magazines all have cut-rate, mass distribution systems in place for political science classes, the author was unable to find any such system for Spanishlanguage newspapers or news magazines. First preference would have been a daily Latin American (or Spanish) newspaper or a counterpart weekly news magazine delivered via air mail at a discount to all students in the class. Even one subscription to a foreign newspaper delivered on this basis turned out to be prohibitively expensive, and in any event only promised to arrive several weeks late. 
A compromise solution was to use El Nuevo Herald (associated with the Miami Herald) as a supplementary source material for the class. This Spanish-language, Miami-based newspaper has good coverage of international news and is especially good on Latin America. Moreover, the newspaper reflects a Latin American perspective of the world in its choice and treatment of stories including pieces by Latin American columnists and editorials.

\section{Advantages}

Teaching mainstream political science courses in a foreign language can help inculcate an international perspective or global vision in students. This involves not just learning more about the world, but also seeing the world-and ourselvesthrough foreign eyes. Instruction, class discussions, and materials in a foreign language all contribute to this end.

A variety of class activities have been keyed to El Nuevo Herald. Every week one student has been responsible for identifying the top three stories in the newspaper. These stories are briefly summarized and then their importance is explainedall in Spanish. Subsequent class discussion-likewise in Spanish-contrasts official and mainstream U.S. views of the stories with perspectives of other countries particularly in Latin America.

Each student also has selected a country to track in El Nuevo Herald during the entire semester. Individual student files on the selected country compiled from the foreign language newspaper have constituted the major source material for two policy papers, each with a maximum limit of two double-spaced pages. (While the source materials for these policy papers were to be in Spanish, the paper itself could be written in English or Spanish.) The first policy paper has involved identifying the top domestic problem of the country and justifying this selection, while the second policy paper has identified the top international problem of the country and explained why it is so important. Class discussions on the policy papers have allowed another opportunity to contrast domestic and international problems as seen by the country in question and by the United States.

The courses have been structured so that the instructor lectures more frequently early in the course. Class presentations by students have been introduced gradually as students become acclimated to instruction in a foreign language. Especially in the early part of the course, class lectures in the foreign language have been interspersed with English-language summaries. Students gradually have gained foreign-language confidence as the courses have progressed, with the added incentive of gaining onethird of the final grade through class participation. At the same time, it

\section{Teaching mainstream political science courses in a foreign language can help inculcate an international perspective or global vision in students.}

has been made clear that no grades would be given on foreign language competency but only on proficiency in political science.

Pew case studies in international relations (from the Pew Program in Case Teaching and Writing in International Affairs) have also been used for the courses and adapted to a foreign language format. Basically this involved following a more structured format than might be required for English-language discussion of the case studies. Prior to a first class session assigned to each case study, the instructor would identify key issues for the class discussion and would assign small groups of students to represent, respectively, both the U.S. and foreign roles or views on these issues. Relying on a Communication-Across-the-Curriculum technique, students would first write an essay on their particular issue from the assigned national perspective; the essays would then be discussed in small discussion groups; rapporteurs from each group would present a consensus or conclusions of each group; and finally general class discussion would focus on reasons for divergencies of interests and identification of contrasting national negotiating strategies.

A similar small group method has been used for a second day of discussion of each case study, but this time the focus has been on ways of reconciling national interests and strategies at different junctures in the crisis. Inasmuch as each group has been responsible for a distinctive national perspective (i.e., Haiti and the United States regarding economic aid relationships), cultural and national differences and difficulties in reconciling them have been dramatized.

Another particularly useful teaching tool is satellite-transmitted, foreign-language news broadcasts and commentaries. The Clemson University language laboratory has been recording weekly news from a Mexican television station for use by my students. The news is timely, the perspective is avowedly Mexican, and issues are selected from weekly news broadcasts that best illustrate themes under discussion in class for that week.

Just as pedagogical methods need to be adapted for teaching political science in a foreign language, so too it is well to modify the usual physical setting. The traditional classroom setting with chairs arranged in formal rows, often anchored in place, militates against an easy, continuous dialogue in a foreign language by a relatively small class. In my case, the dean of the college was able to overcome this obstacle by arranging for all class sessions to be held in a small seminar room with an oval conference table.

As teaching methods have evolved, so too have other aspects of foreignlanguage teaching of political science. Technical terms in international relations, it was thought at first, could be learned piecemeal as the course progressed. But key concepts and terms are so interrelated and pervasive that students need to master the foreign language equivalents as soon as possible. Consequently, when a foreign-language class in political science was offered for the second time, an English-Spanish vocabulary list of key international relations terms was distributed at the begin- 
ning of the course.

Integrating foreign language with political science can add an important marketable skill for students who must compete in a tough job market. Courses taught in political science in a foreign language place students at once in a professional, foreign-language setting requiring concise, articulate expression on technical subjects. This consequently goes well beyond simple language training and can be marketed to employers as such.

Just as there is much to be gained by students from a foreign-language approach, so too can professors benefit. Political science professors need to become more competent in foreign languages. At the same time, there is considerable, if untapped, foreign-language expertise among the political science professoriate in the United States. At my alma mater, fluency in a foreign language is required for an advanced degree in international relations (M.A. and Ph.D., The School of Advanced International Studies of the Johns Hopkins University). A number of other graduate schools have similar foreign language requirements. Nonetheless, this expertise has simply not been oriented toward teaching. Foreign language competence has generally been regarded as a useful tool for political science research and perhaps for the occasional academic exchange in a foreign country.

For U.S. political science professors who are nonnative speakers of English, foreign language proficiency has likewise been irrelevant for the classroom. In fact, a heavy foreign accent can be a real detriment. What foreign language proficiency does confer on them is perhaps some added ease with area studies research and some status as an "insider." Unexploited is the potential foreign-language contribution such professors might make directly in the political science classroom. Similar contributions could be made by political science graduate students who are nonnative English speakers as discussion leaders in a foreign language.

Within the political science profession, there has been a dichotomy between the foreign language competency of a fairly numerous body of professors and the classroom. Often graduate students in political science interested in foreign languages and cultures rightly regard university teaching as a dead end in terms of developing that interest. Practitioners enjoy a contrasting image of using their foreign language skills in professional situations. The political science teaching profession has evolved in such a way as to marginalize the importance and use of foreign languages, but this need not be the case, and the image of the profession can be enhanced in the process. In effect, there is an unexploited foreign language resource that can be used to the advantage of both professors and students.

\section{Integrating foreign language with political science can add an important marketable skill for students who must compete in a tough job market.}

One would like to believe that advantages alone would be sufficient to motivate greater integration of foreign language instruction into the political science curriculum, but added incentives can always help push events in a desired direction. Extra credit could be given for a political science course taught in a foreign language (say, four rather than three semester hours). On completing several such intensive courses, students might be exempted from one required course in their political science major. For example, three four-hour courses in political science in a foreign language might be considered as the equivalent of four required three-hour political science courses in English, inasmuch as the total of each would be 12 semester hours. The course load of professors teaching in a foreign-language track could be calculated in concomitant fashion. Foreign-language tracks or courses in academic disciplines such as political science should be featured prominently on academic transcripts as well. Foreign-language internships might be offered to political science students who excel. Political science

departmental awards also might be added for majors who develop a high level of foreign-language skills.

In addition to frequent inertia in the curriculum, political science professors essentially have no incentive to offer their courses in foreign languages. Language competency at present only pays off insofar as it may assist publication and lead to some foreign-exchange opportunities. If universities are serious about encouraging a global perspective, then foreign-language competency and innovations by professors must be taken into account in the assessment process. The reward structure including rank, remuneration, and retention should be sensitive to foreign-language innovations across the curriculum. For example, service and teaching might be explicitly defined to include and encourage courses in political science in foreign languages.

Change comes slowly, so for the time being, modest plans are being made to extend the foreign-language component of the political science curriculum at Clemson University. I have been planning the addition of other political science courses in Spanish and hope to inaugurate a French-language track for political science courses as well. Professors in other social science disciplines at Clemson may inaugurate foreignlanguage courses as well. As we develop social science courses in foreign languages in these directions, we would be happy to share our experiences, and we look forward to hearing of foreign-language initiatives at other universities.

\footnotetext{
About the Author

\section{Michael A. Morris}

Michael A. Morris is professor of political science at Clemson University, Clemson, South Carolina, where he teaches comparative and international politics. In addition to his background as a

political scientist, he has an M.A. in Hispanic Studies from Middlebury College and the University of Madrid, Spain. He has lectured in a number of foreign countries in English, French, Portuguese, and Spanish including a recent two-year exchange as a Fulbright Professor in Britain.
} 